$\mathbb{P}$ periodica polytechnica

\author{
Social and Management Sciences \\ $16 / 1(2008)[13+20$ \\ doi: 10.3311/pp.so.2008-1.02 \\ web: http://www.pp.bme.hu/so \\ (c) Periodica Polytechnica 2008
}

RESEARCH ARTICLE

\section{Impact of business culture on empowerment}

Ildikó Andó

Received 2008-09-14

\section{Abstract \\ If a Hungarian's father for example is Dutch and his mother} is French, it gives him an understanding of the fact that if something works in one culture, there is a little chance that it will work in another. The situation is the same in business life. If something works in a traditional company culture, there is no evidence that it will work in a modern organization. Consequently, if a leader wants to be successful in leadership, he has to know the values of his team in detail.

Several international and Hungarian researches mapped the Hungarian's characteristics. Researchers claim, that national culture is in strong connection with company culture. According to this theory, company culture determines efficient leadership techniques.

The author of this publication conducted an online survey with 324 respondents of two multinational companies. The main topic of the survey was to examine the relationship between organizational culture and the potentials of applying empowerment. Based on the results of the survey this study reveals the main cultural elements of companies and shows what kind of leadership methods can be used efficiently in special organizational circumstances.

\section{Keywords}

empowerment $\cdot$ company culture $\cdot$ leadership attitude $\cdot$ organizational values

\section{lldikó Andó}

Department of Industrial Management and Economics, BME, Budapest, 1111, Múegyetem rkpt 9., Hungary

e-mail: ando.ildiko@kalidon.hu

\section{Empowering culture}

Although Douglas McGregor presented the essence of empowerment in his "Theory X" and "Theory Y" in 1960, empowerment remains one of the biggest challenges for modern management [11]. While managers take part in trainings year by year in order to develop their leadership competencies, the effect of these trainings can rarely be experienced at the workplace. On the other hand, employees show an increasing need for freedom to make decisions on their own responsibility. Consequently, empowerment is becoming one of the key tools of leading subordinates, and so it should not be ignored.

The world-famous empowerment guru Kenneth Blanchard and his group have researched the delegation of making decisions for many decades. Their results and experience have been published in several books and articles [6,7]. Thus, the question, why a Hungarian $\mathrm{PhD}$ candidate begins further research in this field, arises. Firstly, the existing models of empowerment are based on US and Western-European corporate cultures. It is an unquestionable fact that these cultures differ significantly from the Hungarian culture, which is burdened among others by the legacy of the former communist regime. Secondly, western theories and practices presume an empowering business culture, where the preconditions of empowerment - leaders who are ready to give the right of decision to their subordinates and employees who are ready to make decisions - are given.

By contrast, the first task of managers working in Hungarian companies is to establish the preconditions for an empowering corporate culture. For these reasons, modern western models do not apply to the empowerment issues in Hungary because they are beyond the establishment of an empowering company culture.

In sum it can be said that Blanchard's theory describes a culture at a high level of empowerment, while the Hungarian model identifies an organizational situation with a low level of empowerment. I simply call my approach to describe the Hungarian concept a pre-empowerment model and a pre-empowering business culture. 


\section{Empowerment theories}

Despite differences in western and Hungarian empowerment theories the main elements of Blanchard's model have relevance relationship in the Hungarian situation.

In 1996 Ken Blanchard and his co-authors defined three key elements of empowerment.

- Sharing accurate information with everyone.

- Creating autonomy through boundaries.

- Replacing hierarchical thinking with self-managed teams [6].

Based on international results and personal experiences, the author of this publication developed a theory which identifies four dimensions of pre-empowerment in the Hungarian culture.

- Creating an atmosphere of trust.

- Harmonizing sets of values.

- Willingness to take responsibility for decisions.

- Working in network [1].

As it has been mentioned before there are close connections between Blanchard's and the Hungarian conceptions. Without an atmosphere of trust there is no empowerment. If a leader can not rely on the professional know-how of his problem-solvers, and the employees can not trust the leadership know-how of their leader, the empowerment does not work.

In an atmosphere of trust Blanchard's autonomous and selfmanaged teams can operate only if the sets of values of the leader and his employees are harmonized. Harmonizing means that the manager and his subordinates are mutually ready to accept the norms of the other. Thus they can make decisions based on the same values and goals without any direct and continuous control.

Additionally, Blanchard's autonomy means not only the possibility to make decisions by teams, but also taking responsibility for decisions. In order to be ready for self-management the members of autonomous teams have to be willing to accept responsibility for their choices. Making decisions on somebody's own responsibility is not evident under intimidating circumstances. By means of mutual confidence the leader must make it possible for the problem-solvers to trust in their professional know-how as well as their decisiveness.

Moreover, accurate information can be shared with everyone only if the employees are able to work in a network. In most cases business issues which have strong direct effects on success require the competences of several problem-solvers from different units of the company. In consequence, unless the employees are able to work in a network, necessary information is not available. For this reason the chance of making unfounded decisions increases. Furthermore, people not involved in the decision making process will not support the choice. Finally, hierarchical thinking can not be replaced with self-managed teams without an atmosphere of trust and real decision-makers.
Summarized, Blanchard's empowering culture can only operate effectively if its preconditions are improved by the leaders and their subordinates in a company. Consequently, Hungarian managers have to make huge efforts in the future to develop the recent pre-empowering culture into a real empowering situation.

\section{Culture research}

The findings of western cultural studies suggest national culture has a significant effect on the management style at a company. Undoubtedly, this result applies to Hungarian corporations. This paper maps how the typical character of Hungarian culture influences the business management in the country. We examine the connection between culture and management style because we are certain that if a leader has a comprehensive picture of what kind of values are of high importance to the Hungarian employees, he can use leadership techniques and methodologies, including empowerment, more successfully. First of all we must analyze international culture researches and their findings regarding Hungarians.

We can not talk about national or business culture unless we mention two studies and their respective authors, Geert Hofstede and Fons Trompenaars. Hofstede began his research in the late 1960s. 88000 IBM employee from 72 countries all over the world were involved in his survey. The findings of his research were published in 1980 in a book entitled Culture's Consequences. Based on the responses of IBM employees Hofstede identified 5 different dimensions of national cultures. This article focuses on the first three dimensions with their definitions provided.

- Power distance

Power distance is the extent to which the less powerful members of institutions and organizations within a country expect and accept that power is distributed unequally.

- Individualism versus Collectivism

Individualism pertains to societies in which the ties between individuals are loose: everyone is expected to look after himself or herself and his or her immediate family. Collectivism as its opposite pertains to societies in which people from birth are integrated into strong, cohesive groups, which throughout people's lifetimes continue to protect them in exchange for unquestioning loyalty.

- Uncertainty avoidance

Uncertainty avoidance is the extent to which the members of a culture feel threatened by ambiguous and unknown situations.

- Long- and short-term orientation

- Masculinity versus Femininity (Hofstede - Hofstede, 2005)[10] 
Nearly 30 years ago Hofstede introduced a young man, called Fons Trompenaars to the subject of intercultural management. Trompenaars started a new culture research with the aim of developing a method which examines how cultural differences affected the process of doing and managing business. Today his database consists of more than 50000 participants from more than 100 different countries.

In his research Trompenaars studied 7 different cultural dimensions. Similarly to Hofstede's model we have given the definitions of the dimensions which are relevant to our empowerment approach.

- Universalism versus Particularism

In a universalistic culture, general rules, codes and values take precedence over particular needs and claims of friends and relations. In a particular culture, rules and laws merely codify how people relate to each other. The human friendship and the intimate relationship are deemed more important than the "letter of the law".

- Individualism versus Communitarianism

In an individualistic culture people place the individual before the community. In a communitarian culture people place the community before the individual.

- Specific versus Diffuse

In a specific culture, individuals have a larger public sphere than private one. In their relationships, specific individuals focus on hard facts, standards and contracts. In a diffuse culture, the private sphere of individuals is larger than their public sphere. Their relationships include style, trust and understanding.

\section{- Affective versus Neutral}

In an affective culture, displaying of emotions is natural. In a neutral culture, showing one's feelings overtly is incorrect.

- Achievement versus Ascription

In an achievement-oriented culture, the status of individuals derives from what they have accomplished. In an ascriptionoriented culture, the status refers to the birth, gender, class, education and position of individuals.

- Time

- Internal versus External [14]

Although Hofstede's and Trompenaars' approaches reflect two different perspectives at first sight, we can find common ground between them. According to the examination of Smotherman and Kooros, four out of five of Hofstede's cultural dimensions and five out of six of Trompenaars' dimensions have significant correlation. From the point of view of our preempowerment model, we are concerned with three correlations.
- Hofstede's power distance has a negative correlation to Trompenaars' universalism, individualism and specific dimensions. Power distance maintains a negative correlation to achievement dimension.

- Hofstede's uncertainty avoidance dimension reports significant inverse correlation with Trompenaars' achievement dimension.

- Hofstede's individualist dimension shows a significant positive correlation to Trompenaars' universalism, individualism, specific and achievement dimensions.[13]

Data for Hungary in different cultural dimensions can be found both in Hofstede's and Trompenaars' publications. It must be noted, that in the case of Hofstede's research these values are estimated, based on a personality test. Similarly, in the case of Trompenaars' survey the origin of the data can not be traced.

Based on Hofstede's and Trompenaars' intercultural research, several culture researches have been conducted in Hungary. In this article we analyze two Hungarian surveys, which have strong connection with Hofstede's and Trompenaars' cultural model. One of them is the GLOBE research. GLOBE uses Hofstede's dimensions adding four other elements: human-orientation, performance-orientation, genderegalitarianism and assertiveness. In Hungary 184 managers from 16 different companies completed the GLOBE survey in the early 1990s. (Bakacsi - Takács - Karácsonyi - Imrek, 2002 [5]). The other Hungarian survey was conducted by Zoltan Kovacs $\mathrm{PhD}$ candidate in 2004 and 2005. His findings were published in his $\mathrm{PhD}$ dissertation in 2006. Kovacs' survey is based on Trompenaars' cultural dimensions. Trompenaars' questionnaire was completed by 501 Hungarian participants in Kovacs' research [13].

Table 1 shows the results of the four different culture researches on which we concentrate in our study. In terms of origin and representative sample Kovacs' findings are identified as the most reliable.

\section{Power distance}

Before beginning to reveal connections between Hungarian culture and empowerment, we must answer the question what kinds of relationships there are between national and business culture. According to Trompenaars culture appears at three levels. The highest level is national culture. The second one is the corporate culture, which identifies the culture within a specific organization. The final level is defined as the culture of particular functions within organizations such as production, sales, marketing, etc. Trompenaars' research focuses on the first, national level. As far as the second, organizational level is concerned the researcher claims that the way of doing business is determined by national culture [14]. Similarly to Trompenaars' approach Hofstede insists that in culture "there is no shortcut" to the business world [10]. 
Tab. 1. Results of culture researches in different dimensions

\begin{tabular}{|c|c|c|}
\hline $\begin{array}{l}\text { Hofstede's } \\
\text { dimensions }\end{array}$ & HOFSTEDE [5] & GLOBE [3] \\
\hline Power distance & rather small & large \\
\hline $\begin{array}{l}\text { Individualism ver- } \\
\text { sus Collectivism }\end{array}$ & individualistic & $\begin{array}{l}\text { rather individual- } \\
\text { istic }\end{array}$ \\
\hline $\begin{array}{l}\text { Uncertainty avoid- } \\
\text { ance }\end{array}$ & strong & rather weak \\
\hline $\begin{array}{l}\text { Performance- } \\
\text { orientation }\end{array}$ & only in GLOBE & low \\
\hline
\end{tabular}

After we have made it clear that the same national characteristics appear both in everyday life and work, we can begin to map how Hungarian culture influences the development of empowerment. First of all one of Hofstede's dimensions, the power distance comes into focus. Concerning power distance Hofstede gives a rather small PDI to Hungary $(P D I=$ power distance index). By contrast, GLOBE's findings show a considerable power distance for Hungarians. The question arises, which result is more reliable. In terms of the origin of data GLOBE is well-documented. Moreover, GLOBE documentations are easily available, because the survey was conducted by Hungarian researchers. In the case of Hofstede's survey, the questionnaire completed by Hungarians was different from the original Hofstede's questionnaire. As a result the PDI published by Hofstede is an extrapolated rate. For these reasons GLOBE's data are considered more reliable. According to the GLOBE findings power distance in Hungary (PDI $=5.56$ ) is larger than the world average (PDI $=5.147$ ), and the largest in the Easter European cluster. The higher the PDI value the more characteristic the acceptance of hierarchical inequality in the organization [5]. The score of Hungarian business culture on the Likert scale with seven ordered response levels is 4.42 [4].

How can large power distance be interpreted in the business world? Firstly, according to Hofstede's model centralization is popular in the companies with a large PDI. Centralization means that most of decisions are made not locally but centrally. In this case the right of making decisions is not given to subordinates. The power belongs to the higher positions, regardless of the people, who sit in the chair.

Secondly, managers in a culture with large power distance are unavailable. As a result of unavailability communication is poor between leaders and their subordinates. Ineffective communication has negative effects on the process of harmonizing values. In an organization with a large PDI most of the declared norms do not appear in everyday work. Thus there is a wide gap between the values in words and the values in actions. In

\begin{tabular}{lll}
\hline $\begin{array}{l}\text { Trompenaars' } \\
\text { dimensions }\end{array}$ & $\begin{array}{l}\text { TROMPENAARS } \\
{[9]}\end{array}$ & $\begin{array}{l}\text { KOVÁCS } \\
{[7]}\end{array}$ \\
\hline $\begin{array}{l}\text { Universalism versus } \\
\text { Particularism }\end{array}$ & universalistic & universalistic \\
\hline $\begin{array}{l}\text { Individualism versus } \\
\text { Communitarianism }\end{array}$ & $\begin{array}{l}\text { rather individual- } \\
\text { istic }\end{array}$ & individualistic \\
\hline $\begin{array}{l}\text { Specific versus Dif- } \\
\text { fuse }\end{array}$ & specific & specific \\
\hline $\begin{array}{l}\text { Affective versus } \\
\text { Neutral }\end{array}$ & neutral & neutral \\
\hline $\begin{array}{l}\text { Achievement versus } \\
\text { Ascription }\end{array}$ & $\begin{array}{l}\text { rather } \\
\text { achievement- } \\
\text { orientation }\end{array}$ & $\begin{array}{l}\text { low achievement- } \\
\text { orientation }\end{array}$ \\
\hline
\end{tabular}

this way employees get confused, and they do not know which values are really important in the organization. In pursuit of value harmonization the leader must communicate with his subordinates honestly and continuously. On one hand the norms of managers have to be known to employees. On the other hand managers have to get to know the values of their subordinates. As a consequence, the rigid hierarchy does not support the effective communication or the harmonization of value sets in a company.

In the frame of my PhD study I conducted an online survey in March 2008. The main topics of the survey were organizational culture, set of business values and the leadership attitude. By now two companies joined the survey. One of them is a financial corporation with 214 respondents, and the other one is an industrial company with 110 respondents (Ando, 2008 [2]). In this paper I cite only those results of my research which have strong connections to the Hungarian business culture.

As far as harmonization of sets of values is concerned, I experienced significant differences between the two participating companies of the survey. In both companies I revealed disharmony between organizational and individual sets of values. Regarding the individual values the list of priorities was different in the various groups of employees (male-female, high-level and middle-level education employees, manager or subordinate, different age groups) in one of the participating organizations. By contrast, the individual values showed a homogeneous culture in the other company. The homogeneous individual values offer considerable advantages. For instance, the homogeneous individual culture makes the leader able to create harmony between organizational and individual sets of values quickly and successfully, because it is likely that the impact of his actions would be the same on every group of employees. In contrast with it, in the case of inhomogeneous individual values the actions of the leaders have different effects on different groups of employees. Consequently, if the leaders want to introduce changes, it is more likely that these changes would be supported by more 
employees in the company with homogeneous values than with inhomogeneous ones. Therefore leaders can choose the best way of change implementation if they know the type of set of values of their teams.

Returning to power distance it can be stated, that the effort to harmonize sets of organizational and individual values decreases PDI. If truthful communication, information sharing and recognition for outstanding performance became dominant organizational values, power would be replaced by trust. In the atmosphere of trust empowerment can work efficiently, and the likelihood of the quality of empowered employees' decisions can be raised by harmonized organizational and individual values.

In contrast with a small PDI, large power distance has a negative effect on the atmosphere of trust. In an empowering culture leaders rely on their own experience and on competences of their subordinates. In a hierarchical organization, managers trust in superiors and formal rules. The lack of credible communication and the differences between the norms of leaders and those of their subordinates make building the atmosphere of trust practically impossible.

As a result, in an intimidating company culture problemsolvers are not willing to take responsibility for their risky decisions because they are not sure that their unintentional mistake will not be sanctioned.

It is typical in Hungary that large power distance is accompanied by strict decision-making processes in corporations. Under traditional circumstances relationships between managers and subordinates are limited by regulations. It means that during the decision-making process neither managers nor their subordinates can leave the reporting lines. In this way, rules are creating barriers to forming informal networks that could enable co-decisions.

In sum large power distance can be interpreted as a significant barrier to empowerment. In order to develop empowering culture to be developed Hungarian managers must shift into the direction of smaller power distance.

\section{Individualism and performance-orientation}

As it was mentioned earlier, Smotherman and Kooros [13] found significant positive correlation between Hofstede's individualism and Trompenaars' universalism, individualism and achievement-orientation. For this reason we analyze these cultural factors in a parallel way.

As Borgulya and Barakonyi wrote in their book, some cultures emphasize collectivism against individual creativity and self-realization. By contrast, other cultures focus on individualism creating a competitive work environment [8]. In the dimension of individualism versus collectivism (Hofstede) or communitarianism (Trompenaars) every research described Hungarians as individualists. The decision-making process, motivation and working in groups are crucial areas in an individualistic organization. According to the western culture models in an individualistic group decisions are made on the spot by representatives.
This type of decision-making process is present today in traditional Hungarian state companies where managers in positions have generally an exclusive right to decide. However, due to the individualistic attribute it is assumed that the decisiveness of Hungarian employees can be developed successfully.

In terms of responsibility researchers claim, that in a selforiented organization subordinates require taking individual initiatives, and they are ready to take personal responsibility. Willingness to take responsibility is a critical point in the Hungarian organizational culture, because sanctions for the failures in the former regime posed a threat to employees. Building an empowering work environment the leader must convince his subordinates that even if they make incorrect decisions he trusts them, and mistakes will not be sanctioned.

With regard to the GLOBE survey, Bakacsi and his co-writers are uncertain whether Hungarian employees are ready to take responsibility for their decisions or they only want the right to decide (individualism/collectivism value is 3.91 on the Likert scale with seven ordered response levels 1 ] [8]. Similarly to decisiveness the individualistic behavior of Hungarians presumes readiness for taking responsibility for risky decisions. If the leader establishes the atmosphere of trust in the company, readiness changes into competency.

The results of my online survey indicated, that the motivation for taking responsibility for decisions is extremely low in both companies. In both participating companies the employees are ready to take higher responsibility of their own free will, than it is expected by their leaders. Consequently, leaders should make effort to harness the potential of willingness to take responsibility. The empowerment can be one of the successful tools for giving high responsibility to subordinates. Obviously, empowerment does not mean that the empowering manager gives the full responsibility to his empowered employees. Besides the continuous support for his subordinates, manager has to be able to face the new type of responsibility that is the risk of empowerment.

In contrast with decisiveness and responsibility, an individualistic culture makes the building of an informal network difficult. Both individualism and universalism prefer rules and formal procedures. On the one hand in an individualistic and universalistic work environment, people cerate contact with others from different business units, if the connection is required by rules. In line with this, task prevails over relationship. Besides preference for regulation individualists work alone rather than in groups. On the other hand business issues have become so sophisticated by now that one expert is not enough to make a complex decision. Business affairs require the co-operation of several problem-solvers.

Additionally, strict official reporting lines form a barrier to the free flow of information. If the leader is not able to encourage his subordinates to leave the reporting lines and build

\footnotetext{
${ }^{1}$ The higher the value of individualism/collectivism is the stronger the collectivism is in the company.
} 
informal network between the different business units, the information necessary to make educated decisions is not available for problem-solvers. Consequently, if a company intends to create an empowering culture, leaders have to remove the hierarchical barriers in order to make the flow of information free and co-decision possible.

My online survey revealed significant differences between the two participating organizations in terms of sharing information. These differences refer to the relationship between information systems and leadership attitude. In both companies the information systems support the information sharing process. But in one of the two participants the support by the systems are more considerable than by leadership attitude. The inverse situation can be experienced in the other company. There the support by leadership attitude is stronger than by the systems.

In practice, supportive leadership attitude is absolutely necessary for the successful information sharing activities. If the company lacks supportive leaders, then even the best information systems can not make the flow of information free. By contrast, if the leaders are ready to share information with their subordinates, then the development of information systems could be quick and efficient.

Since the companies allocate large budget for information technology, leaders have to be aware whether the information systems or the leadership attitude create real barrier preventing the free flow of information.

Finally, in terms of decisiveness and responsibility the impact of individualism is positive on empowerment. By contrast, universalism has a negative influence on the establishment of an informal and global network.

Another critical element in cultural dimensions is achievement-focus or performance-orientation. As far as performance-orientation is concerned all researchers agree that achievement-orientation is at low level in Hungarian organizations. Unquestionably, the former culture in Hungary was characterized by ascription-orientation. According to Bakacsi the appearance of achievement-orientation in Hungarian culture can be interpreted as a desire for a performance-focused work environment (performance-orientation value is 4 on the Likert scale with seven ordered response level ${ }^{2}$. The root cause of relatively low performance-orientation is found in the legacy of the socialist regime. In traditional organizations the recognition was not linked to performance. As a result employees were unmotivated to use their capabilities at a higher level than minimally necessary.

By contrast empowerment can not work without effective motivation. In an empowering culture problem-solvers are expected to harness their skills and knowledge to the largest extent. Additionally they are also expected to take responsibility for their risky decisions. A successful motivation system inspires problem-solvers to greater efforts as well as to higher

\footnotetext{
2 The higher the value the stronger the performance-orientation.
}

performance. Concerning achievement-orientation it has been found, that incentives applied by Hungarian managers are not suitable to encourage high performance, and it makes developing an empowering environment ineffective.

In terms of achievement-orientation the results of my survey were the same in both companies. As far as the organizational values are concerned, achievement-focus is the first, most important value among cultural elements. It is not surprising because both participants are big multinational companies. In contrast to achievement-orientation performance recognition is the last value in sequence of the organizational values in both corporations. It means, that while achievement-focus appears in everyday operation, respondents think, that they do not receive proper recognition for their performance.

In a company culture, where performance is not rewarded, subordinates probably do not welcome empowerment. Although performance evaluation systems work in both companies, leaders have to understand, that the system provides only frame for performance evaluation. Performance management is a process that aims at a steady increase of organizational performance. This requires leaders - among others - to give continuous support and feedback to their subordinates. If performance evaluation became a real-time process against a yearly or half-yearly event, it would increase the likelihood of the success creating the atmosphere of trust and apply empowerment by the leaders.

\section{Human-orientation}

Regarding Trompenaars' additional cultural dimensions such as neutrality and specificity a strong direct connection can not be identified between them and empowerment. Despite this fact the neutral and specific character of Hungarian culture exercises an influence on organizational communication. As it is mentioned above communication plays a significant role in building empowering culture. Without honest and continuous discussion a leader can not create an atmosphere of trust. Surveys based on Trompenaars' questionnaire suggest Hungarian organizational culture is characterized by neutral behavior. Revealing emotions is not preferred in a neutral situation. Neutrality does not mean the lack of feelings. But the fact that in these cultures managers tend to avoid expressive and enthusiastic behavior, makes energizing their employees difficult.

The specific characteristic of Hungarian culture can be interpreted in a way that suggests the relationship between colleagues is limited to work. After leaving workplace people withdraw into their private sphere. The specific attribute can not influence the effectiveness of empowerment in a direct way, but if it is examined as an attitude to relationships then it can make developing formal as well as informal networks less effective.

As the results of my online survey indicate the closest cooperation can be experienced inside the structural units in both examined companies. The cooperation between different structural units is less direct than inside them. According to the experiences this phenomenon is typical in Hungarian companies. 
One efficient method to encourage cooperation between business units is to launch projects in which employees from different organizations are involved. Projects across different groups (cross functional teams) support not only the collaboration but also the knowledge and information sharing and the harmonization of values between business units.

GLOBE's findings about low human-orientation value (3.8 on the Likert scale with seven ordered response level 3 , which represents limited contact between managers and their subordinates, are a further warning sign of the fact that Hungarian leaders must make huge efforts to create the atmosphere of trust in their organization. Additionally, as a result of poor interpersonal relationships inside the company managers can not inspire their subordinates to do their best in their jobs and take responsibility for their decisions. To a great extent low human-orientation has a strong correlation with large power distance. A wide gap between leaders and employees can not encourage human-focus. Because of the significant correlation of these dimensions we can claim that their impact on empowerment is the same. Similarly, just as large power distance low human-orientation also forms a significant barrier to empowerment.

Returning back to the results of online survey the priority of achievement-focus against performance recognition indicates low human-orientation. Bringing human-beings into focus in business life is crucial. As Gyoker said, the significant differences between successful and unsuccessful companies lie not in technology but in the competencies of employees [9]. Undoubtedly leaders can not harness the competencies of their subordinates without recognition of their performance.

Regarding the last dimension, Hofstede's UDI (UDI = uncertainty avoidance index), Hungarians are identified as a nation which can cope with uncertainty. In the case of Hungarian culture the explanation of this attitude lies in history. During the period of transition from socialism to a market-based economy people lived under unpredictable circumstances. They had to face numerous changes with uncertain outcomes. As a result Hungarians managed to develop a competence for living together with uncertainty. But there is a different interpretation of UDI. According to Bakacsi et al. it is assumed that Hungarian participants of GLOBE survey interpreted uncertainty avoidance as sense of insecurity (value is 3.56 on the Likert scale with seven ordered response level ${ }^{4}$ [4]. Either way, the attitude of people to business has changed in Hungary dramatically, and this change can support the establishment of modern leadership techniques such as empowerment.

\section{Business culture and development of empowerment}

Table 2 summarizes the impact of cultural dimensions on elements of the pre-empowerment model. The table shows the number of cultural dimensions that inhibit empowerment is sig-

\footnotetext{
3 The higher the value the stronger the human-orientation.

${ }^{4}$ The higher the value of uncertainty avoidance the more stable and regulated the operation of the company.
}

nificantly larger than that of dimensions which support it. Large power distance and low human-orientation are identified as the main barriers to the delegation of the right to make decisions. Their negative influence on empowerment can be detected in every aspect of the pre-empowerment theory. Only individualism and ability to cope with uncertainty can be evaluated as supportive factors in Hungarian business culture in terms of willingness to take responsibility.

Based on these results several questions arise. Two of them are the following:

- Can empowerment work in Hungarian business life?

- Is it worth striving to develop an empowering culture in Hungary despite the present organizational culture?

The answer is undoubtedly YES to both questions. Yes because despite the Hungarian cultural pattern employees require involvement in decisions as well as making decisions on their own responsibility. Yes to the second question because small, isolated empowering cultures live even in the rigid, hierarchical Hungarian companies proving the operability of empowerment. Finally yes because according to the international experience empowerment increases the performance of the organization dramatically.

There is a tendency in business world to develop organizational culture. Culture development is a big challenge for every group. To change an old culture and form a new one generally takes several years. If business leaders at a company are totally committed to the cultural changes and they cope with the failures and difficulties they will benefit from their efforts considerably.

However managers must realize that their investments into the desired business culture can not be successful unless they have deep knowledge of their present organizational values. If the leaders strive to improve their leadership competencies and try to use new leadership methodologies they must do it on the basis of their business culture. Managers will be able to empower their subordinates if they have a clear picture about the values of the organization and those of the employees. The development of empowerment will happen in different ways for instance in an individualist organization with small power distance and in a group which prefers collectivism and hierarchy. Managers need different competencies to be able to empower in USA and in Hungary. For these reasons giving the right to make decisions to problem-solvers can only work effectively if the process and circumstances of empowerment are linked to the business culture of the company.

The results of this study raise the question: What kind of leadership techniques can be applied in Hungarian business cultures in order for empowering work environment to be established. The practical significance of this issue is enormous because if we can identify the characteristics of organizational culture and the leadership attitude, then we can coach leaders in such a way which enables them to empower successfully. 
Tab. 2. Impact of cultural dimensions on empowerment

\begin{tabular}{|c|c|c|c|c|}
\hline \multirow{2}{*}{ Cultural dimensions } & \multicolumn{4}{|c|}{ Factors of pre-empowerment model } \\
\hline & $\begin{array}{l}\text { Creating atmosphere of } \\
\text { trust }\end{array}$ & $\begin{array}{l}\text { Harmonizing sets of } \\
\text { values }\end{array}$ & Taking responsibility & Working in network \\
\hline Large power distance & negative & negative & negative & negative \\
\hline Individualism & & & positive & negative \\
\hline Universalism & & & & negative \\
\hline Low performance-orientation & & & negative & \\
\hline Low human-orientation & negative & negative & negative & negative \\
\hline Neutrality & negative & & & \\
\hline Specificity & & & & negative \\
\hline Weak uncertainty avoidance & & & positive & \\
\hline
\end{tabular}

Moreover, leaders have to be aware that the capability of empowerment is not born with them and it can not be acquired by trainings. Only the personal experience makes the leader able to empower. As Chris Argyris says, leaders have to learn to improve and refine the sense of empowerment.

\section{References}

1 Ando I, Dilemmas of Empowerment - Atmosphere of Trust, $6^{\text {th }}$ International Conference of PhD Students (Miskolc, 2007).

2 , Úton a felhatalmazás felé, CEO Magazin 4 (2008).

3 Argyris C, Az alkalmazottak felhatalmazása: a császár új ruhája, Harvard Business Manager 1 (1999).

4 Bakacsi Gy, Takács S, Honnan - Hová? A nemzeti és szervezeti kultúra változásai a kilencvenes évek közepének Magyarországán, Vezetéstudomány (1998), no. 2.

5 Bakacsi Gy, Takács S, Karacsonyi A, Imrek V, Eastern European cluster: tradition and transition, Journal of World Business (2002).

6 Blanchard K, Carlos P J, Randolph A, The 3 keys to empowerment, Berrett - Koehler Publishers, San Francisco, 2001.

7 _ Empowerment - A felelösség hatalma, SHL Hungary, Budapest, 1998.

8 Borgulya I, Barakonyi K, Vállalati kultúra, Stratégiaalkotás III, Nemzeti Tankönyvkiadó, Budapest, 2004.

9 Gyokér I, Humán-eróforrás menedzsment, Múszaki Könyvkiadó, Budapest, 2001.

10 Hofstede G, Hofstede G J, Cultures and Organizations, McGraw-Hill, NY, 2005.

11 McGregor D, The Human Side of Enterprise, McGraw-Hill, NY, 1960.

12 Kovács Z, Kultúrák versengése a globalizáció korszakában, Pannon Egyetem, Veszprém, 2006. Doktori (PhD) értekezés.

13 Smothermann R, Kooros S, Assessing Cultural Differences: Comparing Hofstede's and Trompenaars' Dimensions, Proceedings of the Conference of the Academy of Business Disciplines, 2001.

14 Trompenaars F, Hampden-Turner C, Riding the Waves of Culture, Nicholas Brealey Publishing, London, 2006. 